\title{
Time trends in schizophrenia mortality in Stockholm County, Sweden: cohort study
}

\author{
Urban Ösby, Nestor Correia, Lena Brandt, Anders Ekbom, Pär Sparén
}

Although mortality in patients with schizophrenia is two to three times higher than that in the general population, little is known about time trends in mortality rates. ${ }^{1-3}$ We aimed to assess mortality over time after a first admission to hospital with schizophrenia. In those patients who died, the cause of death was categorised as natural, cardiovascular, suicide, or unspecified violence.

\section{Subjects, methods, and results}

The Swedish patient register details all psychiatric inpatient treatments since 1 January 1971. Data on residents of Stockholm County (population 1.8 million) whose first admission to hospital with a diagnosis of schizophrenia had occurred between 1976 and 1995 were linked to the national causes of death register, and the date and underlying cause of death were determined in those who had died. Because mortality - and particularly mortality from suicide-is increased in the period after a first admission to hospital, ${ }^{1-3}$ we confined our study to these patients and excluded any who had been diagnosed before 1976. Follow up (in person years) was calculated in relation to sex, five year age group, five year age group and social class, and five year calendar period from the date of a first admission to hospital with schizophrenia to 31 December 1995 or death, whichever occurred first. The expected number of deaths was estimated from mortality rates for the general Stockholm population between 1976 and 1995. Standardised mortality ratios for natural, unnatural, and specific causes of death were calculated for each five year period. Relative excess death risks were estimated through Poisson regression models, controlling for age at diagnosis and length of follow up when appropriate.

Standardised mortality ratios for all causes of death increased 1.7-fold in men and 1.3-fold in women over the study period. The increase was greatest in 1991-5 for men and in 1981-5 for women. Death from cardiovascular causes increased 4.7-fold in men and 2.7-fold in women; suicide increased 1.6-fold in men and 1.9-fold in women; and mortality from unspecified violence increased 3.8-fold in men and 3.4-fold in women (table).

\section{Comments}

Our data indicate increasing mortality among people with schizophrenia. Standardised mortality ratios increased over time for all causes of death, but the appreciable increases in deaths from natural and cardiovascular causes suggest that the somatic health of these patients deteriorated, perhaps because their illness causes them to adopt an unhealthy lifestyle and to be less inclined to seek health care. ${ }^{4}$ High mortality from suicide in schizophrenia patients was also reported in a registry linked study from Denmark. ${ }^{3}$ Mortality from unspecified violence in our study may include cases of suicide.

The changing criteria for hospital admission during the study period meant that proportionately more patients with severe illness were admitted; this represents a potential confounding factor. However, the number of patients admitted to hospital with schizophrenia increased over this time, arguing against the occurrence of selection bias. Diagnostic specificity is

\author{
Department of \\ Clinical \\ Neuroscience, \\ Karolinska Institute, \\ S-171 76 \\ Stockholm, Sweden \\ Urban Ösby \\ consultant \\ Lena Brandt \\ researcher \\ Department of \\ Medical \\ Epidemiology, \\ Karolinska Institute \\ Nestor Correia \\ associate professor \\ Anders Ekbom \\ professor \\ Pär Sparén \\ associate professor \\ Correspondence to: \\ U Ösby \\ Urban.Osby@ \\ nvso.sll.se
}

BMJ 2000;321:483-4

Observed over expected numbers of deaths and relative risks (95\% confidence intervals) for different causes of death in patients first admitted to hospita with schizophrenia, Stockholm County, 1976-95

\begin{tabular}{|c|c|c|c|c|c|c|c|c|c|c|c|c|}
\hline \multirow[b]{2}{*}{ Year } & \multirow[b]{2}{*}{$\begin{array}{c}\text { First } \\
\text { admissions }\end{array}$} & \multirow[b]{2}{*}{$\begin{array}{c}\text { No of } \\
\text { deaths }\end{array}$} & \multicolumn{2}{|c|}{ All causes } & \multicolumn{2}{|c|}{ Natural } & \multicolumn{2}{|c|}{ Cardiovascular } & \multicolumn{2}{|c|}{ Suicide } & \multicolumn{2}{|c|}{ Unspecified violence } \\
\hline & & & $\begin{array}{l}\text { Observed/ } \\
\text { expected }\end{array}$ & $\begin{array}{l}\text { Multivariate } \\
\text { relative risk }\end{array}$ & $\begin{array}{l}\text { Observed/ } \\
\text { expected }\end{array}$ & $\begin{array}{l}\text { Multivariate } \\
\text { relative risk }\end{array}$ & $\begin{array}{l}\text { Observed/ } \\
\text { expected }\end{array}$ & $\begin{array}{l}\text { Multivariate } \\
\text { relative risk }\end{array}$ & $\begin{array}{l}\text { Observed/ } \\
\text { expected }\end{array}$ & $\begin{array}{l}\text { Multivariate } \\
\text { relative risk }\end{array}$ & $\begin{array}{l}\text { Observed/ } \\
\text { expected }\end{array}$ & $\begin{array}{l}\text { Multivariate } \\
\text { relative risk }\end{array}$ \\
\hline \multicolumn{13}{|l|}{ Men } \\
\hline 1981-5 & 761 & 162 & $\begin{array}{c}2.7 \\
\text { (2.3 to } 3.1 \text { ) }\end{array}$ & $\begin{array}{c}1.1 \\
(0.9 \text { to } 1.4)\end{array}$ & $\begin{array}{c}1.8 \\
(1.5 \text { to } 2.2)\end{array}$ & $\begin{array}{c}1.1 \\
\text { (0.9 to } 1.5)\end{array}$ & $\begin{array}{c}2.0 \\
\text { (1.4 to } 2.7)\end{array}$ & $\begin{array}{c}1.5 \\
(1.0 \text { to } 2.3)\end{array}$ & $\begin{array}{c}16.9 \\
(12.1 \text { to } 22.9)\end{array}$ & $\begin{array}{c}1.1 \\
\text { (0.7 to } 1.7)\end{array}$ & $\begin{array}{c}12.6 \\
\text { (6.7 to } 21.6)\end{array}$ & $\begin{array}{c}1.1 \\
\text { (0.5 to } 2.1)\end{array}$ \\
\hline 1986-90 & 831 & 104 & $\begin{array}{c}4.3 \\
\text { (3.5 to } 5.2)\end{array}$ & $\begin{array}{c}1.2 \\
(0.9 \text { to } 1.6)\end{array}$ & $\begin{array}{c}2.0 \\
(1.4 \text { to } 2.7)\end{array}$ & $\begin{array}{c}1.2 \\
\text { (0.9 to } 1.8)\end{array}$ & $\begin{array}{c}4.2 \\
\text { (2.9 to } 6.0)\end{array}$ & $\begin{array}{c}2.9 \\
\text { (1.8 to } 4.7)\end{array}$ & $\begin{array}{c}27.7 \\
(19.9 \text { to } 37.6) \\
\end{array}$ & $\begin{array}{c}1.4 \\
\text { (0.9 to 2.1) } \\
\end{array}$ & $\begin{array}{c}21.1 \\
(11.2 \text { to } 36.1) \\
\end{array}$ & $\begin{array}{c}1.8 \\
\text { (0.9 to } 3.5) \\
\end{array}$ \\
\hline $1991-5$ & 631 & 36 & $\begin{array}{c}9.4 \\
\text { (6.6 to 13.1) }\end{array}$ & $\begin{array}{c}1.7 \\
(1.2 \text { to } 2.5) \\
\end{array}$ & $\begin{array}{c}4.4 \\
\text { (2.3 to } 7.4)\end{array}$ & $\begin{array}{c}2.4 \\
\text { (1.3 to } 4.3 \text { ) }\end{array}$ & $\begin{array}{c}8.3 \\
\text { (3.3 to 17.1) } \\
\end{array}$ & $\begin{array}{c}4.7 \\
\text { (2.1 to } 10.4) \\
\end{array}$ & $\begin{array}{c}47.8 \\
\text { (27.3 to } 77.6) \\
\end{array}$ & $\begin{array}{c}1.6 \\
\text { (0.9 to 2.9) }\end{array}$ & $\begin{array}{c}45.2 \\
(16.6 \text { to } 98.4) \\
\end{array}$ & $\begin{array}{c}3.8 \\
\text { (1.5 to } 9.3) \\
\end{array}$ \\
\hline Test for $t$ & trend & & & $P=0.01$ & & $P=0.02$ & & $\mathrm{P}<0.001$ & & $P=0.07$ & & $P=0.01$ \\
\hline \multicolumn{13}{|l|}{ Women } \\
\hline $1976-80$ & 815 & 259 & $\begin{array}{c}2.1 \\
(1.9 \text { to } 2.4)\end{array}$ & $\begin{array}{c}1 \\
\text { (reference) }^{*}\end{array}$ & $\begin{array}{c}1.7 \\
(1.5 \text { to } 2.0)\end{array}$ & $\begin{array}{c}1 \\
\text { (reference) } \dagger\end{array}$ & $\begin{array}{c}1.7 \\
\text { (1.4 to 2.1) }\end{array}$ & $\begin{array}{c}1 \\
\text { (reference) }^{*}\end{array}$ & $\begin{array}{c}17.1 \\
\text { (12.2 to } 23.3)\end{array}$ & $\begin{array}{c}1 \\
\text { (reference) }^{*}\end{array}$ & $\begin{array}{c}7.4 \\
\text { (2.7 to } 16.0)\end{array}$ & $\begin{array}{c}1 \\
\text { (reference) }^{*}\end{array}$ \\
\hline $1981-5$ & 667 & 176 & $\begin{array}{c}2.6 \\
(2.2 \text { to } 3.0)\end{array}$ & $\begin{array}{c}1.2 \\
(1.0 \text { to } 1.5)\end{array}$ & $\begin{array}{c}2.0 \\
(1.7 \text { to } 2.4)\end{array}$ & $\begin{array}{c}1.3 \\
(1.0 \text { to } 1.6)\end{array}$ & $\begin{array}{c}2.1 \\
\text { (1.6 to } 2.7)\end{array}$ & $\begin{array}{c}1.3 \\
(0.9 \text { to } 1.8)\end{array}$ & $\begin{array}{c}28.5 \\
\text { (20.0 to } 39.5)\end{array}$ & $\begin{array}{c}1.5 \\
(1.0 \text { to } 2.4)\end{array}$ & $\begin{array}{c}9.9 \\
(2.7 \text { to } 16.0)\end{array}$ & $\begin{array}{c}1.4 \\
\text { (0.4 to } 5.0)\end{array}$ \\
\hline $1991-5$ & 551 & 26 & $\begin{array}{c}3.6 \\
(2.5 \text { to } 5.4)\end{array}$ & $\begin{array}{c}1.3 \\
(0.8 \text { to } 2.0)\end{array}$ & $\begin{array}{c}2.1 \\
(1.2 \text { to } 3.5)\end{array}$ & $\begin{array}{c}1.3 \\
\text { (0.8 to } 2.3)\end{array}$ & $\begin{array}{c}5.0 \\
\text { (2.1 to } 4.3 \text { ) }\end{array}$ & $\begin{array}{c}2.7 \\
(1.4 \text { to } 5.4)\end{array}$ & $\begin{array}{c}58.6 \\
\text { (29.2 to } 104.8)\end{array}$ & $\begin{array}{c}1.9 \\
\text { (0.9 to 3.9) }\end{array}$ & $\begin{array}{c}20.1 \\
\text { (0.5 to } 111.7)\end{array}$ & $\begin{array}{c}3.4 \\
\text { (0.4 to 28.6) }\end{array}$ \\
\hline Test for $t$ & trend & & & $P=0.05$ & & $P=0.04$ & & $P=0.002$ & & $P=0.04$ & & $P=0.13$ \\
\hline
\end{tabular}

${ }^{*}$ Controlling for age at diagnosis and follow up.

†Controlling for age at diagnosis. 
another concern, but validation based on medical records of clinical schizophrenia diagnoses in Stockholm County estimated that $80 \%-85 \%$ of these met the operational diagnostic criteria of the Diagnostic and Statistical Manual of Mental Disorders, third edition, revised. ${ }^{5}$

During the study period there were important changes in psychiatric care offered to patients with schizophrenia: outpatient treatment replaced long term inpatient care. In Stockholm between 1976 and 1994, the number of hospital bed days associated with schizophrenia fell by $64 \%$, and this reduction in beds is the most probable explanation for the rising mortality. The same conclusion was drawn in a Danish study reporting increasing mortality from suicide. ${ }^{3}$ Our findings emphasise the importance of monitoring trends in mortality for patients with schizophrenia as well as for other patient groups as indicators of outcome and quality of psychiatric and medical care.

Contributors: UÖ had the original idea for the study, coordinated and designed it, and wrote the paper. NC contributed to the data analysis and discussion of the results. LB contributed to the data analysis, managed the dataset, and helped to write the paper. AE assisted in the design of the study and helped to write the paper. PS assisted in the design of the study, was responsible for designing the data analysis, performed the regression analyses, and contributed to the writing of the paper. PS and UÖ are guarantors.

Funding: Forsknings-och utvecklingsenheten, Stockholms Läns Landsting. This study was supported by grant 19987289 from Stockholm County Council.

Competing interests: None declared.

1 Ösby U, Correia N, Brandt L, Ekbom A, Sparén P. Mortality and causes of death in schizophrenia in Stockholm County, Sweden. Schizophr Res 2000 (in press).

2 Brown S. Excess mortality of schizophrenia. A meta-analysis. Br J Psychiatry 1997;171:502-8.

3 Mortensen PB, Juel K. Mortality and causes of death in first admitted schizophrenic patients. Br J Psychiatry 1993;163:183-9.

4 Brown S, Birtwistle J, Roe L, Thompson C. The unhealthy lifestyle of people with schizophrenia. Psychol Med 1999:29:697-701.

5 Kristjansson E, Allebeck P, Wistedt B. Validity of the diagnoses of schizophrenia in the Stockholm County inpatient register. Nordic J Psychiatry 1987;41:229-34

(Accepted 4 May 2000)

\title{
Rapid diagnosis of falciparum malaria by using the ParaSight $\mathrm{F}$ test in travellers returning to the United Kingdom: prospective study
}

\author{
I M Cropley, Diana N J Lockwood, D Mack, G Pasvol, R N Davidson
}

Lister Unit,

Northwick Park

Hospital, Harrow,

Middlesex HA1 3UJ

I M Cropley

senior registrar in

infection and tropical

medicine

Diana NJ

Lockwood

senior registrar in

infection and tropical

medicine

G Pasvol

professor of infection

and tropical medicine

R N Davidson

senior lecturer in

infection and tropical

medicine

Department of

Haematology,

Northwick Park

Hospital

D Mack

chief medical

laboratory scientific

officer

Correspondence to:

D N J Lockwood,

Hospital for

Tropical Diseases,

London

WC1E $6 \mathrm{AU}$

diana.lockwood@

lshtm.ac.uk

BMJ 2000;321:484-5
A simple diagnostic strip test for Plasmodium falciparum malaria (ParaSight F test, Becton Dickinson Advanced Diagnostics) detects a water soluble antigen, histidine rich protein 2 , which is produced by blood stages of $P$ falciparum. High sensitivity and specificity have been reported for the test in areas where malaria is endemic $^{1-3}$ and in studies of travellers returning from such areas. ${ }^{45}$ We compared the test with standard blood film microscopy in febrile travellers returning to the United Kingdom from such areas.

\section{Subjects, methods, and results}

We studied 160 consecutive patients aged 9-77 years presenting between April 1994 and June 1996 to our unit with a history of fever and travel in the previous year to an area where malaria is endemic. Thin films were stained with Giemsa and read by an experienced microscopist. The ParaSight F test was performed in accordance with the manufacturer's instructions; a pink band indicates a positive result. Each test took less than 10 minutes to perform. Thin films and test strips were read blind to each other.

In 45 patients falciparum malaria was the final diagnosis (table). At presentation 42 cases were detected by microscopy and 42 by the ParaSight $\mathrm{F}$ test. Parasitaemias ranged from $<0.01 \%$ to $15 \%$ of erythrocytes parasitised. In one patient, the test was positive at presentation, and scanty $(<0.001 \%)$ $P$ falciparum trophozoites were detected on blood film only on day 2. In two other patients both the blood film and the test gave negative results at presen-
Results of tests for infection with Plasmodium falciparum and subsequent diagnosis. Values are numbers of patients

\begin{tabular}{lcccc}
\cline { 1 - 1 } Blood film & ParaSight $F$ test & & $\begin{array}{c}\text { F falciparum } \\
(\mathbf{n}=\mathbf{4 5})\end{array}$ & $\begin{array}{c}\text { Other malarial species } \\
(\mathbf{n}=\mathbf{1 1 5})\end{array}$ \\
\hline Positive & Positive & & 41 & 0 \\
\hline Positive & Negative & & 1 & 0 \\
\hline Negative & Positive & 1 & 2 \\
\hline Negative & Negative & 2 & 113 \\
\hline
\end{tabular}

tation but positive results on subsequent days. One patient had a positive test with a negative blood film; three days previously he had had halofantrine treatment for presumed malaria. One patient with pneumococcal meningitis had positive tests over three days with negative daily blood films. The test was negative in one patient with a $P$ falciparum parasitaemia of $<0.01 \%$.

Test results were negative in all 113 other patients who did not have $P$ falciparum infection, including 27 infected with other malarial species (23 with $P$ vivax, 3 with $P$ ovale, 1 with $P$ malariae). Other diagnoses included diarrhoeal disease, dengue fever, typhoid, pneumonia, urinary tract infection, brucellosis, acute myeloid leukaemia, and infectious mononucleosis.

Compared with the final diagnosis, the ParaSight F test used at first presentation had a sensitivity of $93.3 \%$, a specificity of $98.3 \%$, a positive predictive value of $95.6 \%$, and a negative predictive value of $97.4 \%$. 